Zubko Tetiana,

$\mathrm{PhD}$ in Economics, Associate Professor, Kyiv National University of Trade and Economics, Ukraine ORCID 0000-0002-8950-1797,

Kovshova Iryna, Doctor of Sciences(Economics), Associate Professor, National University «Kyiv-Mohyla Academy» ORCID 0000-0001-9013-0180

Kasianova Anastasia, $\mathrm{PhD}$ in Economics, Associate Professor, Kyiv National University of Trade and Economics, Ukraine; ORCID 0000-0003-3155-579X,

\title{
PECULIARITIES OF INVESTING INTO INNOVATION PROJECTS
}

The article presents the results of the evaluation of theoretical explanation and sources of investment into innovative projects in Ukraine. There is considered the essence of the concept «innovative project» and its definition. In the article it is also proposed the scheme which shows an investment support system for the innovative project, taking into account key factors of a business model. There are outlined the main problems in finding the sources of financing innovative projects.

Keywords: sources of financing, project financing, financing instruments, the innovative project, venture capital, peculiarities of project financing, the system of investment support of innovative projects, a business model, key factors.

\section{Зубко Тетяна, Ковщова Ірина, Касьянова Анастасія. Особливості інвестування інноваційних проектів.}

У статті представлено результати проведеної оцінки теоретичного обтрунтування та джерел інвестування інновачійних проектів в Украӥні. Розглянуто суть поняття «інноваційний проект» та удосконалено його визначення. Також у статті запропоновано схему системи інвестиційного забезпечення інновачійного проекту з урахуванням ключових факторів бізнес-моделі. Окреслено основні проблеми у визначенні джерел фінансування саме інноваційних проектів.

Ключові слова: джерела фінансування, проектне фінансування, інструменти фінансування, інновачійний проект, венчурний капітал, особливості проектного фінансування, система інвестиційного забезпечення інноваиійних проектів, бізнес-модель, ключові фактори. 
Introduction. The main factor in the development of the world community, the country and its economy, sectors of economy, activity of enterprises and the society on the whole is considered to be scientific, technological and innovative activity. The focus of business entities on constant introduction of innovations significantly helps them to create competitive advantages, promotes to economic progress. In their turn, there are the investments that ensure innovation. Any innovation is implemented through an investment and innovation project which combines all the necessary processes, their financial and resource support, and evaluates their efficiency. The theory and practice of economic feasibility of innovative projects is still being developed and needs further research.

Formulation of the problem. The purpose of the work is to study the issue of investment support of innovative projects.

Analysis of recent researches and publications. Various aspects of innovative activity are shown in the works of foreign and national scholars. Famous foreign researchers of this issue are: R. Acoff, P. Drucker, D. Clark, W. Larson, N. Augustine, etc. Efficiency of investment has been resarched by such national scientists as: G. Alexander, I. Blank, T. Mayorova, N. Mashina, A. Peresada, V. Romanov, G. Chernova, etc. The issue of financial support of innovative projects has also been considered by the scientists (L. Antonyuk, G. Balayant, V. Geyets, V. Savchuk), but it was not enough. The uncertainty and risk of investing in innovative projects require further research and methodological developments in this field.

Presenting main material. According to the Law of Ukraine "About Innovative Activity» (Articles 1,12) «An innovation project is a set of documents that reveals the procedure and sequence of all the necessary measures (including investment measures) for creation and implementation of an innovative product and (or) innovative products».

In our view, an innovative project is an event or a set of activities grouped into a program or a strategy, which involves the use of either new methodology of performance, or introducing a new organizational form, or producing new products or services.

Table 1

\section{Interpretation of the notion «an innovation project»}

\begin{tabular}{|l|l|}
\hline \multicolumn{1}{|c|}{ Authors } & \multicolumn{1}{c|}{ Definitions } \\
\hline Krupka, M. (2014) & $\begin{array}{l}\text { An event aimed at achieving certain results in the form of the expected } \\
\text { effects }\end{array}$ \\
\hline Saniv, B. (2014) & $\begin{array}{l}\text { Complex programs created to introduce technical, technological or other } \\
\text { innovations and implemented by scientific and designing institutions } \\
\text { over some period of time }\end{array}$ \\
\hline
\end{tabular}




\begin{tabular}{|l|l|}
\hline \multicolumn{1}{|c|}{ Authors } & \multicolumn{1}{|c|}{ Definitions } \\
\hline Balayant, I. (2017) & $\begin{array}{l}\text { The system of interrelated goals and programs for their achievement, } \\
\text { which is a complex of research and development measures, } \\
\text { developmental work, production, organizational, financial, commercial } \\
\text { and other measures, which are appropriately organized, have the set of } \\
\text { project documentation, give effective solution of a certain scientific and } \\
\text { technical task which can be expressed quantitively and result in } \\
\text { innovations }\end{array}$ \\
\hline $\begin{array}{l}\text { Molodozhenya, M. } \\
\text { (2016) }\end{array}$ & $\begin{array}{l}\text { A sum-total of reasonable, interrelated, purposeful decisions and actions } \\
\text { to attract and use the limited number of labor, material, information, } \\
\text { intellectual and financial resources in the framework of innovation } \\
\text { activity of an enterprise, which promote to the achievement of new goals } \\
\text { for development aimed at qualitative changing an enterprise integrally, } \\
\text { obtaining beneficial effect and ensuring competitiveness of an enterprise }\end{array}$ \\
\hline Krasnevych, G. (2010) & $\begin{array}{l}\text { A set of interrelated measures, which are implemented in the course of } \\
\text { the innovation process and which must achieve the goal, which is to } \\
\text { ensure the introduction of innovation, creation and sale of innovative } \\
\text { products of an enterprise with the maximum useful synergistic effect for } \\
\text { the specified time period under certain legal, institutional and resource } \\
\text { limitations }\end{array}$ \\
\hline
\end{tabular}

* made by the authors according to [2, 3, 6, 9].

The notion «an innovation project» is considered simultaneously in three approaches: as a form of targeted management of innovation activities (target approach), the process of innovation (process approach) and as a set of documents (regulatory approach). It is important to note that while using engineering of business processes it is important to develop complete and consistent documentation that accompanies that business process. Typically, this is process regulation which contains a detailed description of each business process (Salyha, K, 2010).

Implementation of an innovative project, like any other project, implies the use of a basic «outline» of a business model. It is feasible to determine here the following key factors: partners, a type of activity, resources, value, customer interaction, distribution channels and customer segments. The so called financial «shell» consists of two diversified financial flows - outflows and inflows.

The mechanism of investment support of innovative projects is quite similar to the scheme of strategy formation at an enterprise. In our opinion, the system of investment support for innovative projects is formed in accordance with the principles of strategic planning. In the figure 1 there is shown the developed system of investment support for an innovative project, taking into account the key factors of a business model. 

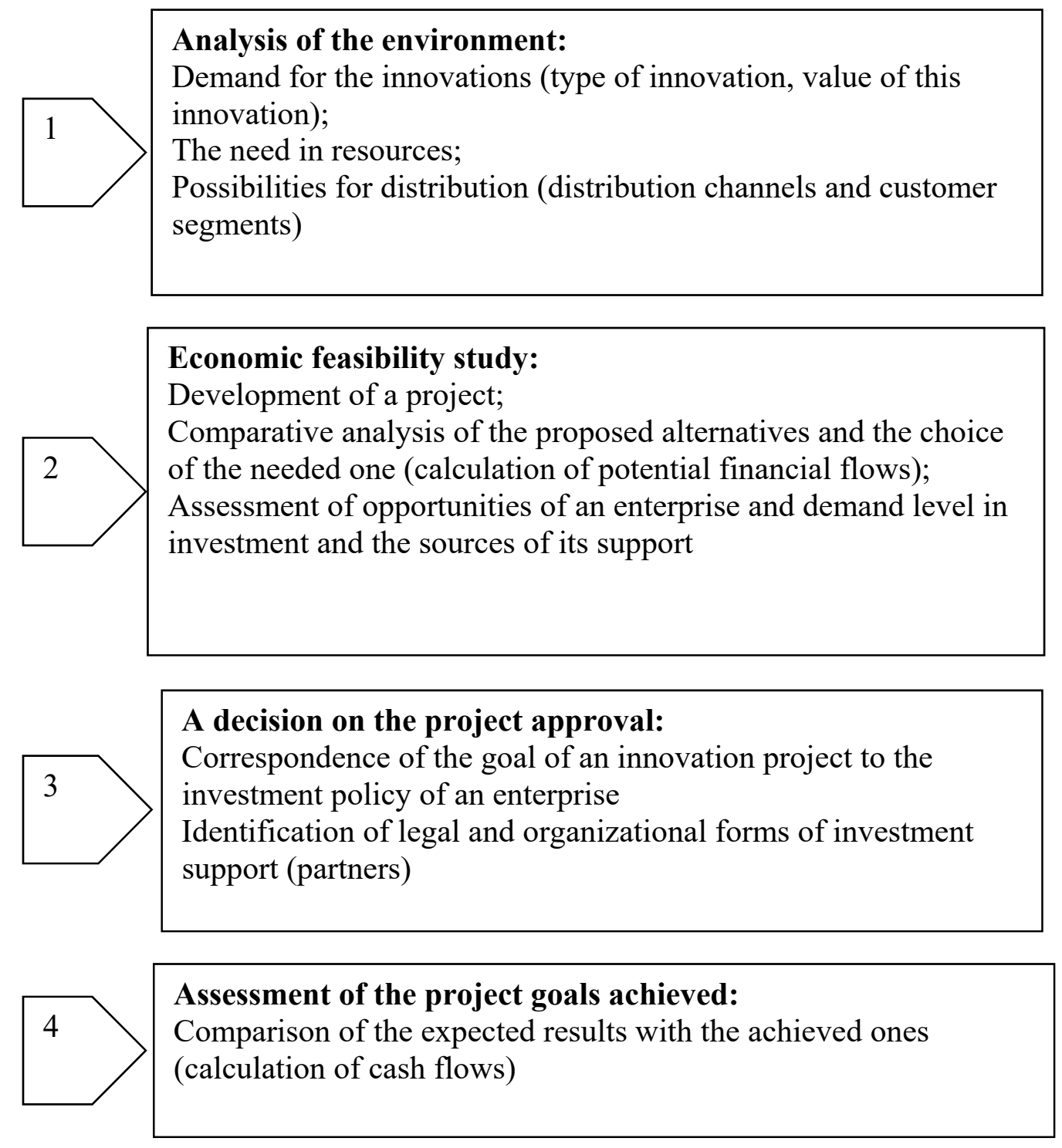

Fig. 1. A System of Investment Support of an Innovation Project

The main condition for investing into an innovative project is a properly formed strategy of an enterprise development and a business model which is based on it. It is the business model that will not only confirm the «viability» of an innovation project, but also motivate other participants (investors, suppliers, consumers) to implement the above project.

According to the elaborated business model, it is easy to apply a balanced scorecard. This system of indicators, in their turn, provides evaluation of enterprise activity in order not only to assess the achieved level of enterprise development, but also the possibilities of its improvement.

Implementation of innovative projects is highly dependent on the related research in the country. Information about the number of the employees engaged in $\mathrm{R} \& \mathrm{D}$ according to the staff category is given in the table 2 . 
The Number of the Employees Working on the Research and Developments, According to theStaff Category

\begin{tabular}{|l|l|l|l|l|l|l|l|l|}
\hline \multirow{2}{*}{ Staff category } & \multicolumn{4}{|c|}{ Staff } & \multicolumn{5}{c|}{$\%$} \\
\cline { 2 - 9 } & 2015 & 2016 & 2017 & 2018 & 2015 & 2016 & 2017 & 2018 \\
\hline In total & 122504 & 97912 & 94274 & 88128 & 100 & 100 & 100 & 100 \\
\hline researchers & 90249 & 63694 & 59392 & 57630 & 73,67 & 65,05 & 63 & 65,39 \\
\hline technicians & 11178 & 10000 & 9144 & 8553 & 9,125 & 10,21 & 9,699 & 9,705 \\
\hline Support personnel & 21077 & 24218 & 25738 & 21945 & 17,21 & 24,73 & 27,3 & 24,9 \\
\hline $\begin{array}{l}\text { Those who have } \\
\text { scientific degree: }\end{array}$ & & & & & & & & \\
\hline Doctors of Science & 17330 & 7091 & 6942 & 7043 & 14,15 & 7,242 & 7,364 & 7,992 \\
\hline PhD & 22340 & 20208 & 19219 & 18806 & 18,24 & 20,64 & 20,39 & 21,34 \\
\hline
\end{tabular}

* made by the authors according to [4, 7].

Unfortunately, the number of employees in these categories is steadily declining.

In 2018 , the share of research performers in the total employed population was $0.54 \%$, including researchers $-0.35 \%$. According to Eurostat, in 2016 this highest share was in Denmark (3.18\% and 2.2\%), Finland (3.04\% and 2.26\%), the United Kingdom (2.29\% and 1.68\%), and the Netherlands (2.28\% and $1.39 \%)$; the lowest in Romania $(0.54 \%$ and $0.34 \%)$, Cyprus $(0.87 \%$ and $0.62 \%)$, Bulgaria $(1.09 \%$ and $0.71 \%)$ and Poland (1.08\% and 0,83\%). [4, 5]

The considerable share of $\mathrm{PhDs}$ and $\mathrm{PhDs}(\mathrm{PhDs})$ among $\mathrm{R} \& \mathrm{D}$ performers was $29.3 \%$, among researchers $-44.7 \%$. More than half of the total number of $\mathrm{PhDs}$ and PhDs (PhDs) who have carried out research and developments, worked in public sector organizations, $35 \%$ in higher education, $5 \%$ in business sector $[4,7]$.

The dynamics of the volume of tne completed scientific and technical works for the period 2014-2018 is shown in the table 3.

Table 3

Domestic Expenses for the Implementation of Scientific Research and Developments According to the Type of Work in 2014-2018 (UAH, millions)

\begin{tabular}{|c|c|c|c|c|c|}
\hline Staff category & 2014 & 2015 & 2016 & 2017 & 2018 \\
\hline In total & 9487,5 & 11003,6 & 11530,7 & 13379,3 & 16773,7 \\
\hline $\begin{array}{c}\text { Fundamental } \\
\text { scientific } \\
\text { research }\end{array}$ & 2452,0 & 2460,2 & 2225,7 & 2924,5 & 3756,5 \\
\hline $\begin{array}{c}\text { Applied } \\
\text { scientific } \\
\text { research }\end{array}$ & 1882,7 & 1960,6 & 2561,2 & 3163,2 & 3568,3 \\
\hline
\end{tabular}




\begin{tabular}{|c|c|c|c|c|c|}
\hline Staff category & 2014 & 2015 & 2016 & 2017 & 2018 \\
\hline $\begin{array}{c}\text { Scientific and } \\
\text { technical } \\
\text { developments }\end{array}$ & 5152,8 & 6582,8 & 6743,8 & 7291,6 & 9448,9 \\
\hline
\end{tabular}

* made by the authors according to [4].

Over the last five years there has been an increase in research spending. If we adjust these figures to reflect inflation rates, we get a slightly different picture of costs: a significant reduction in research costs in 2016, afterwards the cost curve went increasing.

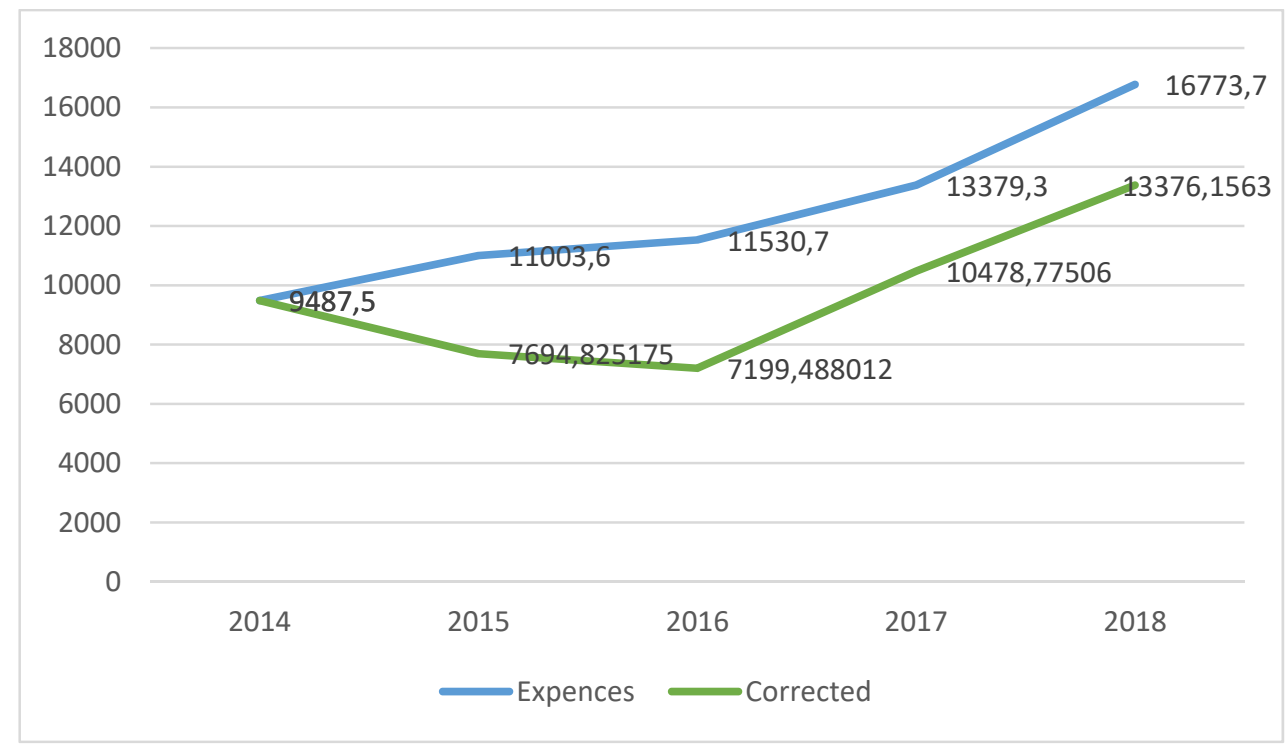

Fig. 2. Expenses for Scientific Research

As it is known, investment resources can be formed from two different sources: own ones (self-financing) and loan ones.

The net sales, depreciation, involved part of current assets are the part of current assets. At present, in the context of political, financial and economic crises, only large enterprises, with relatively steady profitability dynamics, resort to this source of financing.

In 2018, total expenditures for the implementation of R\&D by the organizations' own resources amounted to UAH 16773.7 million, including labor costs UAH 8553.0 million, other current expenses - UAH 7456.3 million, capital expenditures - UAH 764.4 million UAH, where the expenses for the purchase of equipment were 588,0 million $[4,7]$.

The dynamics of changes in the sources of financing domestic costs for the implementation of research and development is shown in the table 4. 
Table 4

Sources of Financing Domestic Expenses for Doing Scientific Research, UAH, millions

\begin{tabular}{|l|c|c|c|c|}
\hline \multirow{2}{*}{ Sources } & \multicolumn{3}{|c|}{} \\
\cline { 2 - 5 } & 2015 & 2016 & 2017 & 2018 \\
\hline In total & 11003,6 & 11530,7 & 13379,3 & 16773,7 \\
\hline Budgetary sources & 3992,2 & 3910,8 & 4896,4 & 6223,1 \\
\hline Including: state budget & 3915,4 & 3700,9 & 4740,1 & 5703,1 \\
\hline Own sources & 2783,3 & 1146,0 & 1340,9 & 1610,3 \\
\hline Government sector sources & 281,6 & 361,6 & 718,7 & 1140,6 \\
\hline Entrepreneurial sector sources & 1713,4 & 3369,5 & 3007,8 & 3941,8 \\
\hline Higher education sector sources & 3,7 & 7,4 & 8,9 & 16,8 \\
\hline Private not-for-profit organizations' sources & 0,1 & 2,8 & 2,8 & 16,8 \\
\hline Foreign sources & 2077,6 & 2550,3 & 3262,8 & 3639,9 \\
\hline Other sources & 150,0 & 182,3 & 141,1 & 184,5 \\
\hline
\end{tabular}

* made by the authors according to [4, 5]

The largest share of research funding is budgeted, and the least is from higher education sector organizations and private nonprofit organizations.

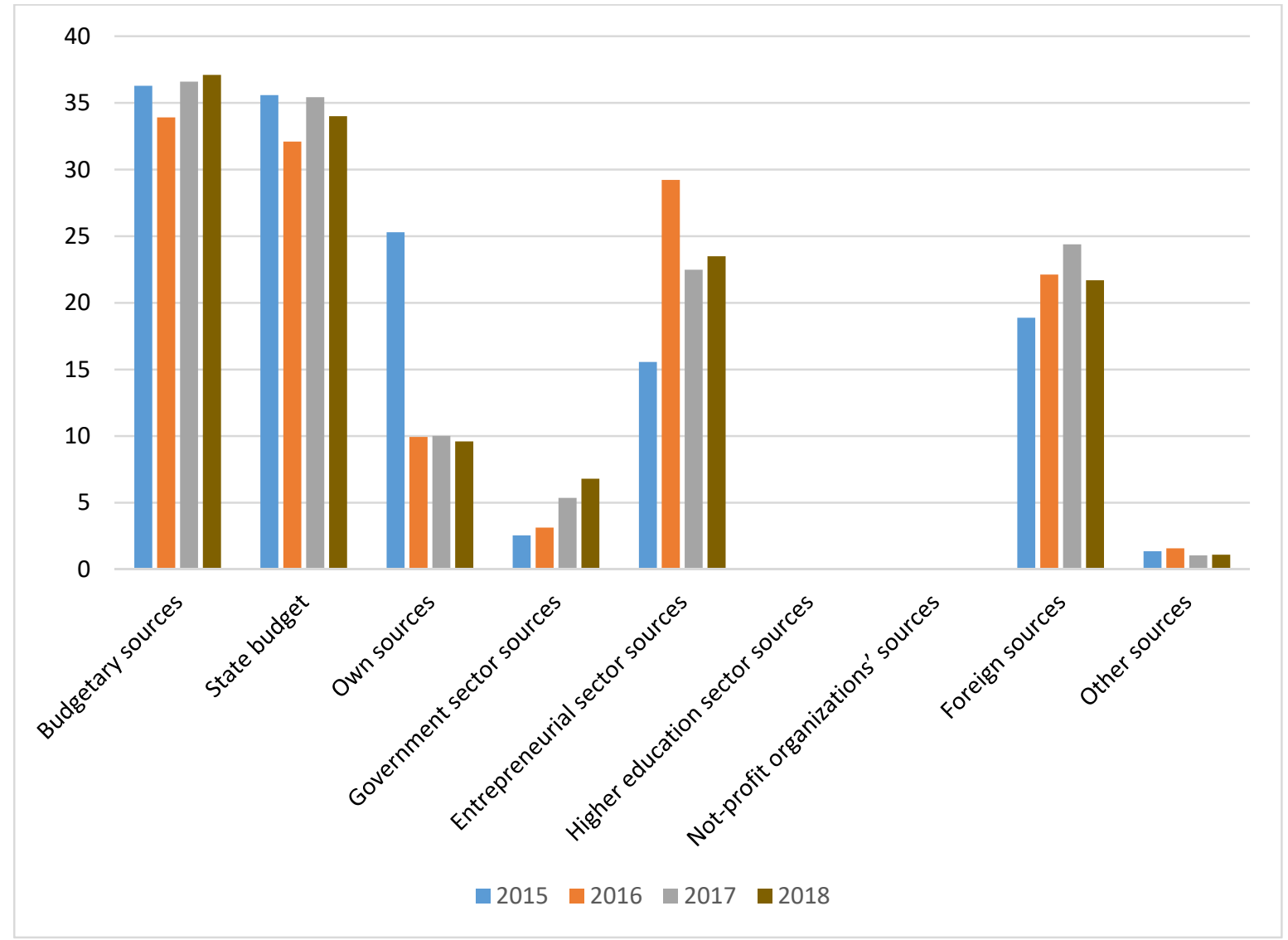

Fig. 3. Dynamics of Main Sources of Financing for 2015-2018 
The borrowed and attracted sources of investing enterprises include:

- investment bank loans;

- targeted financing;

- target state credit;

- grants;

- credit lines of international financial institutions.

Investment resources on credit have a longer life cycle and a high degree of risk. At present, because of the crisis of the Ukrainian economy, banking institutions prefer to finance the current activity of an enterprise, rather than innovation and investment.

Public investment is very low because it comes at the expense of the State Budget, ministries and agencies in Ukraine and is hardly used because of the long-term crisis in financial and industrial spheres.

One form of investment is venture investing. There are over 650 venture capital funds, but their use is concentrated in construction and financial sectors. Venture funds are the most risky for investors compared to other co-investment institutes, but this is offset by broad investment opportunities, in particular by greater profits and benefits.

In 2018, in Ukraine the UVCA conducted venture and direct investment market research together with Deloitte, which made the analysis of the investments made by Ukrainian startups in 2017, and actively participated in the development of a survey for investors and funds. The results of the study indicate that 2017 was a record year in the history of the Ukrainian venture business - \$258.6 million was raised for startups, which is three times more than in 2016. This is confirmed by the fact that Ukrainian startups are creating highly competitive products that can meet the needs of consumers around the world [8]. The existing shortcomings in regulatory support for venture investment hinder its development.

Grants and international technical assistance as an investment tool are provided by international organizations. The largest partners in this field for Ukraine are the United States of America and the European Union. Canada, Sweden, Switzerland, Japan, Turkey, Denmark also provide significant assistance. International technical assistance is implemented through various forms: expert advice, scholarships, financing education and training, research grants, intellectual property rights and technology, and more.

The use of grants has its own peculiarities:

- grant funds are awarded on a competitive basis;

- these funds are classified as «targeted financing» in accounting and are provided irrevocably;

- the grantee is obliged to submit financial reports on the use of funds;

- the quipment purchased at the expense of the grant cannot be sold or leased until the end of the project. 
Lately another form of investment financing has been developing rapidly, that is crowdfunding. Usually crowdfunding is applied to nonprofit organizations or social enterprises. In fact, crowdfunding is about attracting funds for the project from many individuals. One of the most famous crowdfunding platforms in the world is Kickstarter, which was founded in 2009 and is focused on the implementation of extremely innovative projects. This platform receives $5 \%$ of all funds raised. Ukraine is represented a little on this platform because the main obstacle is the problem of withdrawal of funds. The peculiar features of this platform are two requirements for its recipients: the avaliability of an account on Amazon Payments, the presence in the team of a representative of one of the countries where this platform is officially launched (Yeliseyeva, L., 2017, Okhrimenko, O, 2018).

In addition, there is an international crowdfunding platform Indiegogo, with which the Ukrainians work. The projects supported by this platform are focused on improving the standard of living and the environment. Lately several wbsites have appeared in Ukraine. The most famous are biggggiidea.com and «Спільнокошт» (CommunityCost). Ukrainian Crown Funding has a predominantly socio-cultural focus.

Conclusion. Due to the procedure of investing into an innovative project to implement it, there are some peculiarities of this process. Investment support for innovative projects can take the form of: self-financing, lending, government and venture investment, grants, international technical aid. The study of this issue allows us to distinguish some organizational, legislative, and political obstacles.

There emerged the need to draw attention of state institutions, legislators and society to the need for simplification of procedures, guarantees of investment protection in innovative projects, since there are no other ways to improve production processes in Ukraine.

\section{REFERENCES}

1. Yeliseyeva, L.V. (2017). Kraudfandyng $\mathrm{v}$ Ukrayini: problemy ta perspektyvy $\mathrm{v}$ konteksti zarubizhnogo dosvidu [Crowdfunding in Ukraine: problems and prospects in the context of foreign experience]. Naukovyi visnyk Mizhnarodnoho ghumanitarnoho universytetu - Scientific Bulletin of the International Humanities University, 1(23), 8-11. Retrived from http://www.vestnik-econom.mgu.od.ua/ journal/2017/23-1-2017/4.pdf

2. Kramarchuk, S.P. @ Lubkei, N.P. (2018). Teoretychni aspekty upravlinnia innovaciynymy proektamy na vitchyznianykh pidpryiemstvakh [Theoretical Aspects of Management of Innovation Projects at Domestic Enterprises]. Ghlobalni ta nacionalni problemy ekonomiky - Global and national problems of economy, Vol 23, 252-255. [In Ukrainian] 
3. Molodozhenia, M. (2016). Innovaciyni proekty pidpryiemstv torhivli. [Innovative projects of trade enterprises]. Ekonomika Ukrayiny -Ukraine economy. 4(653), 92-103.

4. Research and Innovation in Ukraine: statistical yearbook [Naukova ta innovatsiyna diyalnist $v$ Ukrayini: statystychnyy zbirnyk]. Kyiv, State statistics committee of Ukraine, 2018, p. 178.

5. Rozrobka metodychnoho pidkhodu $\mathrm{z}$ formuvannya proektiv investycijnykh biznes-planiv rozvytku pidpryjemstv leghkoyi promyslovosti z urakhuvannyam orientyriv strukturno-innovaciynoyi polityky [Development of a methodological approach for the formation of projects of investment business plans for the development of light industry enterprises, taking into account the guidelines of structural and innovation policy] [Text]: monograph / [Ighnatieva I. A., etc.; ed. by I.A. Ignatieva]; Kiev. Nat. University of Technology and Design. - Kyiv: KNUTD, 2014. $-431 p$.

6. Salyha, K.S. (2010) Ekonomichne obghruntuvannya innovaciynykh proektiv [Economic grounding of innovative projects] monoghrafiya [Text]: monographKlasych. pryvat. un-t. - Classic Private Univ. - Zaporizhzhya: KPU, $404 \mathrm{p}$.

7. Sayt Derzhavnoyi sluzhby statystyky [Website of the State Statistics Service] Retrived from http://www.ukrstat.gov.ua/druk/publicat/Arhiv_u/01/Arch_ ukr_zb.htm

8. Sayt Nacionalnoyi asociaciyi venchurnogho kapitalu [Website of the National Venture Capital Association] Retrived from http://www.nvca.org.

9. Upravlinnya innovaciynymy proektamy $\mathrm{v}$ umovakh mizhnarodnoyi integhraciyi [Tekst]: monoghrafiya / [O. O. Okhrimenko ta in.]; Nac. tekhn. un-t Ukrainy «Kyiv. politekhn. in-t im. Ighorya Sikorskogho». - Kyiv: KPI im. Ighorya Sikorskogho, 2018. - $260 \mathrm{~s}$. [Management of innovative projects in the conditions of international integration [Text]: monograph / [O. O. Okhrimenko, etc.]; Nat. tech. University of Ukraine «Kyiv. Igor Sikorsky Polytechnic Institute». - Kyiv: KPI, 2018. $260 \mathrm{p}$. 